\title{
U.S./NATO-Russia and Countering Ideological Support for Terrorism: Toward Building a Comprehensive Strategy
}

\author{
Sharyl N. Cross *
}

\section{Introduction}

The United States policy community has defined countering ideological support for terrorism (CIST) as a vital priority in the overall effort to combat terrorism worldwide. ${ }^{1}$ In the aftermath of the tragic bombings in London and Madrid and the school hostage incident in Beslan, policymakers and scholars in Europe/Eurasia are also beginning to devote greater attention to examining the significance of the "battle of ideas” for responding to challenges posed by radical religious extremist movements within their respective nations. ${ }^{2}$ Any successful CIST effort will demand unprecedented levels of agreement regarding major objectives, communication, and coordination among nations committed to protecting the world community from the devastation and loss incurred as a result of terrorist acts inspired by religious extremism.

While countering ideological support for terrorism cannot provide the ultimate "silver bullet" solution for defeating terrorism worldwide, there is no question that addressing the "hearts and minds" of those to whom terrorist ideologies direct their appeal is one critical dimension necessary to undercut the influence of radical terrorist movements over the long term. Yet, although the United States and other nations are devoting increasing attention and resources to developing means to discredit the ideology of Al Qaeda, Salafist jihadists, or other affiliated Islamist groups, no single country can claim to have found a blueprint for the best method to counter militant religious extremism or to de-legitimize the ideological foundations of terrorism. In fact, former

\footnotetext{
Dr. Sharyl N. Cross is Professor of National Security Studies at the George C. Marshall European Center for Security Studies in Garmisch-Partenkirchen Germany. The author would like to express appreciation for research support for this article provided by the Marshall Center Director's Sponsored Research Grant and the Kennan Institute for Advanced Russian Studies/Woodrow Wilson International Center for Scholars. The views expressed in this article are those of the author and do not reflect the official policy or position of the George C. Marshall European Center for Security Studies, the U.S. European Command, the Department of Defense, or the U.S. Government.

1 See National Security Strategy of the United States of America (Washington, D.C.: The White House, March 2006), 9-11, available at www.whitehouse.gov/nsc/nss/2006; Chairman of the Joint Chiefs of Staff, National Military Strategic Plan for the War on Terrorism (Washington, D.C.: Department of Defense, 1 February 2006), 24-25; and author's briefing/ interviews, United States Department of State, November 2006.

2 See The European Union Strategy for Combating Radicalisation and Recruitment to Terrorism (Brussels: Council of the European Union, 25 November 2005); see also Olivier Roy, “Europe’s Response to Radical Islam,” Current History 104 (November 2005): 360-64.
} 
U.S. Secretary of Defense Donald Rumsfeld recently assessed America's performance in "the battle of ideas taking place," giving a near failing grade of a " $\mathrm{D}$ or $\mathrm{D}+$. ."3

An effective strategy to de-legitimize the messages or myths used by terrorist groups must be based on a deep understanding of the unique circumstances in each context. No two regions of the world are necessarily alike with respect to vulnerability to the appeal of the ideology/myths purveyed by terrorists. Contemporary Islamist extremist groups (including Sunni radicals, Salafist Islamists, Shia radicals, and others) can share certain core beliefs, perceived enemies, or objectives, but there are also obviously significant ideological, theological, and tactical differences among these groups that must be recognized. We should approach the complex issue of developing strategy aimed at dissuading populations from turning to radical violent ideologies by seeking the involvement of those familiar with local conditions, social traditions, and values.

This paper explores the potential for building cooperation between the United States/NATO and Russia in countering ideological support for terrorism. Since 9/11, the U.S./NATO and Russia have made significant progress in forging cooperation in counterterrorism efforts, primarily through the mechanisms of the NATO-Russia Council (NRC) and the U.S.-Russia Working Group on Counterterrorism (CTWG). The confluence of interests shared between the United States and NATO member countries, Russia, and other nations throughout the world community make the issue of countering the ideological impulses that fuel terrorism a common security priority that will only become more important in coming decades. A strong international anti-terror alliance can help to deter threats, but any fracture or perceived division should only be expected to encourage terrorists to exploit these weaknesses. Forging greater unity among nations of the transatlantic community in their efforts to reach out to partner nations in the Muslim world with respect to the most fundamental elements in countering the appeal of religious extremism can begin to establish the unprecedented level of global cooperation needed to diminish terrorist threats to open, vulnerable societies throughout the world.

\section{Foundation for U.S./NATO-Russia Cooperation in Countering Ideological Support for Terrorism}

Russia's central concern with the terrorist challenge has tended to focus on the threat emanating from Chechnya and surrounding regions of the North Caucasus. Prior to 9/11, Russian President Vladimir Putin had attempted to focus international public attention on terrorist training camps in Afghanistan and the penetration of radical violent

3 “Rumsfeld: We’re Losing Battle of Ideas,” Carlisle Sentinel (28 March 2006). 
Islamist groups in Eurasia and the Balkans. ${ }^{4}$ Immediately following the 9/11 attacks, Putin was the first among world leaders to offer his support to the Bush Administration. Putin described the Chechen situation and the attacks of 9/11 as constituting a "threat to the entire civilized world." In fact, Dr. Ayman Al-Zawahiri offers a vision in his book, Knights Under the Prophet's Banner, that would unite the Chechens and Caucasian mujahideen in what he calls a "mujahid Islamic belt to the South of Russia" enlisting sympathetic Muslims in Central Asia, Afghanistan, Iran, Turkey, and extending to the east in Pakistan, linking with mujahideen movements in Kashmir. ${ }^{6}$

There are no official statistics on the number of Muslims in Russia. Figures range from three million to thirty million, with most sources estimating between eighteen and twenty million, geographically concentrated in the large cities and the Volga-Ural and North Caucasus regions. ${ }^{7}$ Demographic trends indicating declining birth rates among Orthodox ethnic Russians compared with relative growth among Russia's Muslim population suggests the potential for shifting political and social influence in the future. While the bulk of Russia's Muslims - who are primarily of the Sunni, Hanafist, and Sufi traditions - simply seek to practice their faith in peace, adherents of the anti-Sufi New Islamic Movement and radical Shahidists and Salafists share the objective of reconstituting the "pious Caliphate" or imposing a fundamentalist Islamic state. ${ }^{8}$

While there has been no single assault in Russia resulting in loss of thousands of lives, such as the September 11 attacks in the United States, the nation has suffered a series of terrorist incidents over the past several years. These include apartment bombings in Moscow and Volgodonsk in 1999; Shamil Basayev's invasion of Dagestan in 1999, proclaiming Islamic jihad against Russia; the Dubrovka theater hostage incident in October 2002; a series of subway bombings; and the downing of two passen-

4 For additional discussion of Vladimir Putin's response to Russia's terrorist challenge, see Sharyl Cross, "Putin's Turn Toward the West: Russia, US/NATO and the War on Terrorism Post-September 11,” in Post- Communist Countries in the Globalizing World, ed. Konstantin Khudoley (St. Petersburg, Russia: St. Petersburg State University Press, 2004); and Sharyl Cross, "Russia's Relationship with the United States/NATO in the U.S.-led Global War on Terrorism,” Journal of Slavic Military Studies 19 (2006). Also see Rouben Azizian, "Russian-American Strategic Relationship in the Aftermath of September 11,” paper presented at the $35^{\text {th }}$ National Convention of the American Association for the Advancement of Slavic Studies, Toronto (20-23 November 2003).

5 For further analysis of Putin's motives in responding to 9/11, see Cross, "Putin’s Turn Toward the West.”

6 See Ayman Al-Zawahiri, Knights Under the Prophet's Banner (London, Al-Sharq al-Awsat, in Arabic); excerpts translated in English in FBIS Translated Text, Document \# GMP200201080000197 (2 December 2001).

7 For discussion and documentation on Russia's Muslim population estimates, see Shireen T. Hunter, Islam in Russia: The Politics of Identity and Security (New York: M.E. Sharpe, 2004), 42-45.

8 For discussions of various trends within Islam and radical Islamists within Russia, see Hunter, Islam in Russia, 46-93; and Dmitry Gorenburg, "Russia Confronts Radical Islam," Current History (October 2006). 
ger airlines by Chechen women suicide bombers in August 2004. These attacks culminated in the tragic school siege in Beslan in September 2004, an incident that carries similar cultural resonance in Russia to that of the 9/11 attacks in the U.S.

The Chechens possess a distinct identity spanning centuries and a history of defiant resistance against the Russians, a legacy that is glorified in a mountain warrior tradition honoring death in battle against an enemy of overwhelming advantage. With the dismantling of the Soviet state in 1991, the Chechens recognized the opportunity to join the wave of previously forcibly subjugated people in the Baltics, Central Asia, and the Caucasus who were seeking recognition as autonomous nations. Though not initially prompted by external instigation, over time the Chechen conflict took on greater international dimensions. The two wars in Chechnya and the conflicts in the South Caucasus and Central Asia provided targets for the penetration of international extremist Wahhabist networks, who provided funding for weapons and military training as well as jihadist fighters. It is well documented that $\mathrm{Al}$ Qaeda sent forces to train in Chechnya. ${ }^{9}$

The Chechen situation is likely to continue to present difficulties for the Russian leadership. As a result of migration from Chechnya following Russia's military incursions in 1996 and 1999, the Chechen population has been dispersed throughout Russia, creating a community base within major cities that can be used to support the orchestration of terrorist campaigns. Beyond seeking greater autonomy from Moscow, Chechens hold territorial claims that include portions of the Stavropol Krai and Dagestan.

Russia's National Security Concept of January 2000 identifies terrorism as a "serious threat to national security," and states that "international terrorism is waging an open campaign to destabilize the Russian Federation...."10 Moscow officials have instituted the legal means for addressing domestic terrorist threats and have begun regularizing relations among the anti-terrorist organizations established in various regions of the country. ${ }^{11}$ Russia's response to the terrorist threat places a priority on foreign cooperation, as revealed in the National Security Concept: "to fight [terrorism] requires unification of efforts by the entire international community. ... There must be effective collaboration with foreign states and their law enforcement agencies, and also with the international organizations tasked with fighting terrorism. ... Broad use must

9 For a discussion of Al Qaeda's involvement in the Caucasus, see Igor Plugatarev, "Local Conflicts 2005/A Sluggish War on the Caliphate,” Nezavisimoye Voyennoye Obozreniye 49 (December 2005); “Al Qaeda Among the Chechens,” Christian Science Monitor (7 September 2004); "European Terror Suspect Got Al Qaeda Training,” CNN.com (6 February 2003), available at www.cnn/2003/US/02/06/sprj.irq.alqaeda.links; and Ariel Cohen, "After Maskahdov: Islamist Terrorism Threaten North Caucasus and Russia,” Backgrounder Report No. 1838 (published by the Heritage Foundation) (1 April 2005), at www.heritage.org/ Research/RussiaandEurasia/upload/76370_1.pdf.

10 National Security Concept of the Russian Federation, Rossiyskaya Gazeta (18 January 2000).

11 "Russia: Terrorism Provokes Flurry of New Legislation,” Nezavisimoye Voyennoye Obozreniye (8 April 2005); and V.I. Moltenskoy, Yu.A. Martsenyuk, and S.G. Chekinov, "Ob Organizatsii Antiterrorististicheskoi Deyatel’nocti Gosydarstva,” Voennia Mysl 1 (2005). 
be made of international experience in dealing with this phenomenon, and there must be a well coordinated mechanism for countering international terrorism."12 Russia's Minister of Foreign Affairs, Sergei Lavrov, has affirmed that "the global nature of the terrorist threat testifies that security in today's world is indivisible.... We must bear collective responsibility for making the world secure. ... The fight against terrorism should unite states rather than oppose them to each other."13

In the aftermath of 9/11, some major accomplishments in U.S.-Russian bilateral cooperation in counterterrorism include: Russia's support in permitting basing access in the first phase of the global war on terrorism; FBI-FSB cooperation in intercepting weapons transfers between terrorists; and collaboration in disrupting terrorist financing.

The U.S.-Russia Working Group on Counterterrorism (CTWG) has been the primary mechanism for facilitating bilateral counterterrorism cooperation. The Working Group includes both regional (Afghanistan, Balkans, Central Asia, Southeast Asia, etc.) and functional (intelligence, law enforcement, WMD, terrorist financing, counter narcotics) sub-groups. ${ }^{14}$ Participants from both Washington and Moscow describe the group as it developed from pursuing a more "general" and "theoretical" agenda prior to 9/11, into a much more task-oriented body with clear schedules and deadlines in specific functional areas following the attacks of September $2001 .{ }^{15}$ Participants have noted that the official sessions tended to avoid raising controversial issues, such as the intervention in Iraq and human rights in Chechnya. ${ }^{16}$ However, participants in Washington and Moscow report that there were opportunities to discuss these difficult issues and others in the less formal sessions and in private conversations. ${ }^{17}$

${ }^{12}$ National Security Concept of the Russian Federation, Rossiyskaya Gazeta (18 January 2000).

13 Sergei Lavrov, "Statement at the $59^{\text {th }}$ Session of the UN General Assembly," 23 September 2004, published in International Affairs (Moscow) 6 (2004).

14 U.S. Department of State/Office of the Spokesman, "Joint Press Statement by U.S.-Russia Working Group on Counterterrorism,” 1 April 2004.

15 Author's interviews with Andrei A. Chupin, Former Head of the Section of North America, Ministry of Foreign Affairs of the Russian Federation, March 2004; Nerissa J. Cook, Director, Office of Policy and Global Issues, Bureau of European and Eurasian Affairs, U.S. State Department, April 2004 and November 2004; and Vladimir Andreyev, Deputy Director of the Department of New Challenges and Threats, Ministry of Foreign Affairs of the Russian Federation, June 2005. Ibid.

17 For example, Undersecretary for Political Affairs R. Nicholas Burns and Russia's Deputy Foreign Minister Sergey Kislyak noted in a press briefing following the December 2005 meeting of the Working Group that, while the proposed controversial legislation that would regulate the activity of NGOs in Russia was not part of the formal dialogue, it was suggested that there were opportunities to discuss this and other issues in private diplomatic exchanges taking place in conjunction with the Working Group gathering. Remarks to the press by Undersecretary for Political Affairs R. Nicholas Burns and Russian Deputy Foreign Minister Sergey Kislyak, Osobnyak (Moscow) (2 December 2005). 
Both U.S. and Russian participants emphasize that one should not overstate the Working Group's potential for success, but those involved conclude that it did help in reaching greater consensus on certain issues, building confidence, and accomplishing important concrete tasks to enhance security. Both sides state that the periodic sessions have provided a valuable forum for exchanging information that contributes to enhancing the capacity to respond to the terrorist challenge on multiple fronts.

In terms of NATO-Russia cooperation in counterterrorism efforts, consultations in the first NATO-Russia Permanent Joint Council (PJC) had collapsed during the Kosovo war in 1999 because Russian officials believed that the Council failed to provide a meaningful channel for Russian input into NATO decision making. Putin brought a pragmatic approach to Russia's foreign policy, recognizing the importance of ties with Western nations for Russia's future security and economic quality of life. In spite of Russia's strong and consistent objection to NATO enlargement throughout the 1990s, Putin sought to cooperate with NATO nations in the area of counterterrorism. The primary mechanism for cooperation is the NATO-Russia Council (NRC), established to replace the PJC at the NATO-Russia Summit in Rome in May 2002. The NRC provided for Russia's direct participation in the decision-making meetings among member nations, rather than including provisions for consultation with Russia only after NATO members had reached decisions, as in the previous PJC arrangement.

NATO and Russia have taken concrete steps to enhance counterterrorism cooperation, including making pronouncements condemning terrorist acts; issuing statements agreeing to collectively fight terrorism; and outlining specific areas of cooperation. ${ }^{18}$ In 2002, the NRC sponsored joint conferences devoted to the role of the military in combating terrorism. Col. Gen. Yu.N. Baluyevskiy, writing in Voennaia Mysl, commented quite favorably on these sessions and the level of "mutual understanding" between Russia and NATO concerning the need to both "preempt" terrorist attacks and the means necessary for countering terrorism. ${ }^{19}$ NATO and Russia convened periodic working groups devoted to enhancing counterterrorism security measures, and they have engaged in scenario briefings examining lessons learned from instances such as the London and Moscow mass transit attacks. The NATO-Russia Action Plan on Terrorism called for a "pragmatic" and "goal oriented" effort that would deepen cooperation in intelligence sharing related to WMD, destruction of excess munitions, control

18 “NRC United in Condemnation of Recent Terrorist Attacks in Russia,” 7 September 2004; available at www.nato.int/docu/update/2004/09-september/e0907a.htm.

19 Yu. N. Baluyevskiy, "Rossiya i NATO: Printsipy vzaimootnoshyeniy problemy i perspektivy sotrydnichestva,” Voennaia Mysl 6 (2003): 12-17; "Russia to Join Partnership with Status of Forces Agreement,” 21 April 2005, available at www.nato.int/docu/update/2005/04-april/ e0421a.htm. 
over transfers of man-portable air defense systems (MANPADS), and other provisions. ${ }^{20}$

Most recently, NATO-Russia cooperation in counterterrorism moved to a new level with Operation Active Endeavor, which includes provisions for the first use of secure communication between NATO and Russian warships and the first ever deployment of a team of NATO trainers aboard a Russian warship. NATO's Operation Active Endeavor evolved from the Article V response to the 9/11 attacks. In February 2006, NATO-Russia Council Defense Ministers gathered informally in Taormina, Italy to exchange views on priorities for the remainder of 2006 and beyond. Emphasis was placed on continuing cooperation in counterterrorism efforts, including supporting intelligence exchanges and joint threat assessment.

The U.S.-Russia Working Group on Counterterrorism (CTWG) has created a basis for ongoing and routine task-oriented consultation and cooperation. Shared interests of the United States and Russia in the area of counterterrorism have led to cooperation, in spite of other strains in the bilateral relationship. The recent initiatives in counterterrorism forged under the framework of the NRC have helped to assuage concerns in Moscow that the previous PJC was "too vague" or "undefined."21 For NATO, leading initiatives to develop cooperation in counterterrorism serves the objective of defining clear purposes for a tried and tested alliance in the post-Cold War era. Thus, in the aftermath of 9/11, a foundation has been established to advance U.S./NATO-Russia cooperation in counterterrorism. Addressing the "hearts and minds" of vulnerable audiences, and countering the ideological impulses that motivate contemporary, violent, extremist groups can take the U.S./NATO-Russia relationship in counterterrorism to the next level. Developing common approaches among the U.S., NATO, and Russia promises to contribute to building the broadest possible worldwide support aimed toward unraveling the sources that fuel the ideological support for contemporary terrorist networks.

\section{The Transatlantic Community and the Question of Countering Ideological Support for Terrorism}

In the aftermath of 9/11, the United States took a comprehensive global approach to combating terrorism, while Russia and other European nations tended to place greater

20 “NATO-Russia Action Plan on Terrorism," 9 December 2004, available at www.nato.int/ docu/basictxt/b041209a-e.htm; see also "NATO-Russia Council Agrees on Plan to Fight Terrorism,” 8 December 2004, available at www.nato.into/docu/update/2004/12-december/ e1209b.htm.

21 Among many illustrations of assessments that might be cited, Dr. Andrei Kelin, Deputy Director, Department of European Cooperation of the Ministry of Foreign Affairs of the Russian Federation, concludes that the NRC has "already shown its viability and efficacy." He notes favorably that the tasks of the 2002 Rome Summit were fulfilled by exploring means for cooperation between Russia and NATO in the areas of terrorism, proliferation of weapons of mass destruction, and drug trafficking. See Andrei Kelin, "Russia-NATO: Toward a New Stage of Interaction,” International Affairs (Moscow) 51:1 (2005): 34-42. 
priority on utilizing resources to address domestic terrorist threats. Nevertheless, international collaboration among the transatlantic community in counterterrorism efforts continues to advance on multiple levels, including intelligence sharing, intercepting terrorist financial networks, and homeland defense. In the aftermath of recent terrorist assaults in Europe and Russia, there has emerged an ever-greater realization that effective strategy can no longer address domestic and international aspects of the threat separately. ${ }^{22}$ Recent NATO documents and programs include cooperation in counterterrorism among the major defining missions for the Alliance.

In 2005, the European Union issued The EU Strategy for Combating Radicalisation and Recruitment to Terrorism, which specifically addressed the issue of extremism:

Radicalisation of certain Muslim individuals in Europe is a relatively recent phenomenon. Even those areas of Europe where radicalization is not a major issue at present, or where large Muslim communities do not exist, could become targets for extremists. The EU will continue to develop its collective understanding of the issues, listening to Muslims, and others, comparing national situations and establishing a European picture. ... The key to our success will be the degree to which non-governmental groups-communities, religious authorities and other organizationsacross Europe play an active part in countering the rhetoric of the extremists and highlighting their criminal acts. ${ }^{23}$

The White Paper on Domestic Security Against Terrorism issued in 2005 outlines France's doctrine for dealing with terrorism, and includes an entire section devoted to the "Battle of Ideas." 24 While the French reject references to a "war" on terrorism, the "fight" or "battle" of ideas includes a strategy focused on promoting the basic values of the democratic tradition as a foundation for countering religious extremism. ${ }^{25}$ James Wither observes that the U.K. strategy concentrates on addressing the inequalities and lack of opportunity that contribute to Muslim radicalization, legislation to combat radicalism, and engaging the Muslim community. ${ }^{26}$

Russian officials have emphasized the importance of avoiding a real or perceived "clash of civilizations" with the Muslim world. The perspective from Moscow tends to

${ }^{22}$ Author's interviews conducted with officials at the Ministry of Foreign Affairs, Russian Federation, 27 October 2006. See James Wither, “A Work in Progress: The United Kingdom’s Campaign Against Radicalization," paper delivered at the conference entitled "Countering Ideological Support for Terrorism/Lessons Learned and Future Policy: Interdisciplinary, Theological, and International/Regional Perspectives,” Marshall Center, Garmisch-Partenkirchen, Germany, 25 September 2006 (published in this volume).

23 The European Union Strategy for Combating Radicalisation and Recruitment to Terrorism (Brussels: Council of the European Union, 25 November 2005). "Winning the Battle of Ideas," White Paper on Domestic Security Against Terrorism (Paris, 2005), 113-23. Ibid.

${ }^{26}$ Countering International Terrorism: The United Kingdom's Strategy, Cm. 6888 (July 2006); see also Wither, “A Work in Progress,” 12. 
identify the unique cultural contribution that Russia can make to "bridge" the conflict between Western and Islamic nations. For example, Dr. Mikhail Titarenko, Director of the Institute of the Far East of the Russian Academy of Sciences, offered the following statement:

... culture and traditions are as important as economy ... for mutual understanding and cooperation. ... This is also important for identifying Russia's specific role as a bridge and a factor in the West-East dialogue. There is a rich Muslim culture in Russia, the culture of twenty million Russians living in Russia. This fact can be used to demonstrate our respect to the contributions of world culture made by Muslims and Arab culture. ... The leaders of Muslim countries developed an inferiority complex because their self-esteem was impaired. They will positively respond to any representation of a great power and great culture talking to them on equal terms. ${ }^{27}$

Russian officials and policy analysts recognize that it is important to engage Muslim communities in shaping perceptions and countering the appeal of radical violent Islamists. V.I. Moltenskoy, Yu. A. Martsenyuk, and S.G. Chekinov argued in a 2005 article published in Voennaia Mysl that the "main efforts" of anti-terrorist government activity should include "in the ideological and religious sphere ... active cooperation with religious and spiritual leaders who stand for aiding the state in the war on terrorism and on spreading with their assistance the idea that no religion in its pure form accepts the methods of struggle used by the terrorists...."28 In 2004, the office of the Russian President held a major conference in Moscow, involving the participation of foreign policy officials with Islamic religious clerics and leaders of other faiths, representatives of cultural organizations, and international participation of ambassadors from several Muslim nations. ${ }^{29}$ The purpose of the forum was to draft a "consistent strategy for relations between Russia and the Islamic world.,30

Anatoly Saffonov, who holds the position (created in 2004) of special envoy of the Russian Federation's president on issues of international cooperation in the struggle against terrorism and international crime, has advocated preventing the misuse of religion by terrorists and countering the appeal of terrorist ideology as major topics for international collaboration. ${ }^{31}$ Addressing the ideological foundations of terrorism is

27 Mikhail Titarenko, “The Islamic World and Russian Foreign Policy,” International Affairs (Moscow) 4 (2005).

28 Moltenkoy, et al., “Ob organizatsii,” 22-27.

29 ITAR-TASS News Agency, “Moscow to Host Conference 'Islam Against Terrorism,”” 3 June 2004.

30 Ibid.

31 Author's interviews with Dr. Vladimir Andreev, Deputy Director, Department of New Threats and Challenges, Ministry of Foreign Affairs of the Russian Federation, and Dr. Igor Neverov, Director, North America Department, Ministry of Foreign Affairs of the Russian Federation, 27 October 2006; and discussions with officials of the U.S. State Department, November 2006. This position was created following the Beslan tragedy in 2004, and Anatoly Saffanov was the first appointment to the position. 
consistent with the focus of the Russian counterterrorism policy community on the importance of addressing the "root causes" of terrorism. ${ }^{32}$

Although there are certainly differences between the United States, European nations, and Russia with regard to appropriate areas of emphasis, terminology, and strategies in addressing the ideological foundations of terrorist movements, there is a growing consensus that this is a critical dimension of the overall global counterterror effort. Through greater collaboration and discussion of issues and actual cooperation in the coming years, these nations should be able to improve their levels of coordination and effectiveness in countering violent religious extremism.

\section{Comparing the Ideological Factor in the Cold War and the Contemporary Struggle Against Terrorism}

The Cold War was won and lost by the power of ideology and values. More important than the widening gap in the strategic nuclear balance or the outcomes of regional conflicts was the fact that peoples of the nations of the former Soviet empire ultimately embraced the values of the West, including democracy, capitalism, and freedom. The central significance of the ideological struggle between communism and democracy has led the policy community to compare the importance of ideas in the Cold War with the contemporary struggle against terrorism. The great ideological struggle of the beginning of the twenty-first century comes down to the question of whether the vast bulk of the Muslim world would prefer democracy, capitalism, and freedom or the way of life offered by Al Qaeda and its affiliates that would reconstitute an Islamic imperial caliphate under the movement's version of absolute sharia rule. ${ }^{33}$

There are several major differences that distinguish the ideological dimension in the contemporary struggle with Islamist extremism from that involved in defeating communist ideology. The United States unquestionably held the moral high ground in the Cold War, which contributed to undermining the legitimacy of communism. Democratic ideals and values and the appeal of the Western standard of living inspired transformation of the communist order. In today's world, the sad truth is that the credibility of the United States is constantly called into question, and even traditional allies resent America's power and what is widely viewed as an arrogance of American presence throughout the world. General Carlton W. Fulford, USMC (Ret.) observes that "disclosure-no matter how real or sensationalized—of U.S. torture, atrocities, lack of

32 Author's interview with Dr. Igor Neverov, Director, North America Department, Ministry of Foreign Affairs of the Russian Federation, 27 October 2006.

33 An important distinction within Islam is that, while Sunni/Salafist radicals seek to institute a totalitarian caliphate, for the future Shia Muslims believe that they can only passively await the inevitable return of the Twelfth Imam (al Mahdi) to bring about a perfect spiritual state of peace and justice. However, among Shia Muslims there is a small but influential radical strain, represented by Iranian President Mahmoud Ahmadinejad and within Hezbollah and others that holds that, by accepting the duty to take action (including instigating violence or war in preparation for apocalyptic confrontation), the conditions for the return of al Mahdi can be accelerated. 
due process, renditions to 'black site' prisons, etc., have seriously damaged our image as the 'city on a hill...." "34 While embarrassing atrocities such as Abu Ghraib are hardly consistent with American values or intentions, the United States cannot afford such mistakes in an environment where perceptions are so critical. In the long-term struggle to defeat the ideology of the extremists, American policy makers and society must consider carefully how national values, intentions, and aspirations are projected throughout the world. Given the complex challenges presented by an increasingly transnational international environment, it will be important to find better and more efficient ways to work cooperatively with diverse cultures. Maintaining moral credibility, consistency, and being perceived as well-intentioned will be critical for building the basic trust necessary to dissuade those who look to terrorists to provide what seems to many to be the only alternative to an international order that is viewed as unjust or illegitimate.

The problems of U.S. credibility not withstanding, it must be recognized that the current ideological struggle may be more challenging only because Islamist ideology is not being imposed by force, as was the case in the Soviet experience, but rather emerges organically from within Muslim societies. The ideological/philosophical foundations of contemporary Islamist extremism were cultivated over centuries, and most recently in the writings of scholars and religious leaders from within the Muslim world, such as Hasan al-Banna (1906-49), Sayyid Abul ala Mawdudi (1903-79), Sayyid Qutb (1906-66), and others. ${ }^{35}$ Salafist/Wahhabist theology provides the spiritual and ideological underpinnings for Al Qaeda and affiliated militant Islamist groups. Arguably these writings and views rooted in references to religious tradition and culture could hold far more inspirational appeal than did the imposition of the alien philosophical/ideological belief system of communism.

The growth of information technologies, particularly the Internet, also makes the current ideological threat far more difficult to manage. Islamist extremist terrorists have been nothing less than masterful manipulators of the cyber arena. Terrorist groups have skillfully harnessed Internet technology to recruit followers, disseminate literature, and instantaneously broadcast beheadings and other outrageous acts of violence. Effective management of the information medium is critical to shaping the impressions and judgments that viewers form, and to influencing the ultimate consequences of these

${ }^{34}$ General Carlton W. Fulford, Jr., USMC (Ret.), for the conference "Countering Ideological Support for Extremism: Challenges and Implications," Connections: The Quarterly Journal 5:3 (Winter 2006): 3-6.

35 Sayyid Qutb, "Jihad in the Cause of God," reprinted in Voices of Terror: Manifestos, Writings and Manuals of Al Qaeda, Hamas, and other Terrorists From Around the World and Throughout the Ages, ed. Walter Laqueur (New York: Reed Press, 2004). For an excellent summary of the contributions of the influence of these writings in the development of Islamist radicalism see Mark A. Gabriel, Journey Into the Mind of an Islamic Terrorist (Lake Mary, FL: Front Line, 2006), 20-26. 
viewers' actions. Every effort must be made to ensure credible, consistent, reliable, honest, and efficient management of information. ${ }^{36}$

\section{A Containment-Like Strategy}

The containment strategy introduced by career foreign service officer and diplomat George F. Kennan in 1947 provided an overarching direction for countering the Soviet threat on a global scale. The containment doctrine formed the essence of U.S. strategy for the Truman Administration and for every succeeding administration during the decades of the Cold War. The notion of countering Soviet expansionism ultimately to contain the influence of communism focused strategic planning, executive attention, and resource allocations toward a single threat objective. Kennan's approach called for integrating military, political, socio-economic, and psychological instruments to achieve the aim of opposing expansion "whenever or wherever" the Soviets attempted to advance. The distinguishing features of the strategy identified in Kennan's seminal "Mr. X" article published in Foreign Affairs in 1947 included a "long-term," "patient," "firm," and "vigilant" commitment directed to counter a clearly defined threat. ${ }^{37}$

While the policy communities on both sides of the Atlantic recognize that combating terrorism and countering ideological support for terrorism may present the most significant and daunting strategic challenge of our time, what is lacking is a unified and integrated approach to "contain"—or, more ambitiously, to "roll back"-the appeal of Islamist extremists. The strategy should be "containment-like" in that it must include careful coordination of multiple instruments aimed at supporting an overarching comprehensive strategy, and in that it requires sustained commitment over a period of not just a few years or a single administration, but for the next several decades. This approach must be broadly orchestrated to include information, political, economic, social, religious, moral/ethical, and policy dimensions. Such a strategy will have to be well integrated and coordinated not only within the U.S. government's various agencies (State, OSD, etc.), but also internationally among nations that share the strategic assessment that assigns priority to countering religious extremist ideologies that serve to legitimize terrorism.

It must be recognized that countering ideological support for terrorism will involve much more than simply responses in the realm of public diplomacy. An adequately funded and skillfully orchestrated public diplomacy effort can offer one means of an overall strategy, but it is only one component. As we develop a CIST strategy, we should begin with the fundamental assumption that perception—or even every element

36 This point was made by Lt. Col. Fred T. Krawchuk in "Strategic Communication: An Integral Component of Counterinsurgency Operations," Connections: The Quarterly Journal 5:3 (Winter 2006): 35-50.

37 See George F. Kennan, American Diplomacy, 1900-1950 (Chicago: University of Chicago Press, 1950); and John Lewis Gaddis, Strategies of Containment: A Critical Appraisal of Postwar American National Security Policy (New York: Oxford University Press, 1982). 
that might influence perceptions-must be considered. We must constantly evaluate and re-evaluate how our actions, behavior, messages, and policies are interpreted.

Compared with the era of the Cold War, in the increasingly transnational security environment of the twenty-first century, dialogue within the U.S. government and especially in international forums may become even more necessary to build consensus on terminology, objectives, and execution of policy. No single nation working alone will be able to confront and defeat the worldwide threat of Islamist extremism. Strategy must be developed and coordinated among multiple international partners. Maintaining excellent communication will be integral to forming and refining strategy and sustaining the robust network necessary to deal with this complex challenge.

International gatherings of nations focusing on developing cooperation in counterterrorism efforts, such as the NATO-Russia Council and the bilateral U.S.-Russia Working Group on Counterterrorism (CTWG), provide promising venues for addressing this issue. Any "hearts and minds" strategy coordinated among multilateral or bilateral international groups must involve reaching out to Muslim nations and communities. Working through the development of CIST programs, engaging partners familiar with local cultures and traditions will be critical to achieving progress. We should promote greater appreciation for the potential contributions of NGOs, clerics and religious leaders, educators, and the private sector to challenging the ideology perpetrated by extremists. As collaboration develops at the traditional state-to-state level and among communities, there should be an accompanying momentum toward addressing this issue on the basis of shared strategic objectives.

\section{Building an Actionable Agenda in Countering the Ideological Appeal of Religious Extremism}

In attempting to build a comprehensive "hearts and minds" strategy, every effort should be made to clearly communicate that we reject any notion of a "clash of cultures" or "clash of civilizations" between the West and the Muslim world that would ultimately lead to violent confrontation. There are fundamental differences between non-Muslim and Muslim cultures, values, and traditions. However, the consequences of allowing these distinctive features to once again descend into a large-scale religiocivilizational based war as in the past would likely result in unthinkable losses, given the greater availability of tools of mass destruction in the contemporary international security environment. It is imperative to work to foster consensus among non-Muslim and Muslim nations committed to protecting civilian populations from harm by those who distort the religious teachings of Islam for political purposes.

There have been some reported successes in reforming young recruits to terrorist movements through interventions of religious authorities, but for the most part there is little hope for negotiating or altering the fundamental objectives or convictions of the committed Islamist militant extremist. The fanatic core adherents are driven by a vision of a glorious past and rage against an international order that they deem unjust, immoral, and fundamentally divorced from God and all that is sacred. An author of several fundamental texts of Islamist radicalism, Sayyid Abul Ala Mawdudi, set the foun- 
dation for transforming the international order decades ago: "the objective of Islamic jihad is to eliminate the rule of a non-Islamic system and establish in its stead an Islamic system of state rule. Islam does not intend to confine this revolution to a single state or a few countries; the aim of Islam is to bring about universal revolution." ${ }^{38} \mathrm{Be}-$ cause justification for violence can be found among radical clerics and in differing interpretations of references in the Koran, both secular communities and devout Muslims face difficulties in challenging the extremist agenda. ${ }^{39}$

This should not suggest that secular open societies are locked in an irreconcilable clash with the vast bulk of Muslims throughout the world. "Sacred terrorists" have emerged throughout history to distort the teaching of religious traditions in many faiths and cultural contexts. Influential representatives of the world's Muslim communities openly reject the tactics and vision offered by the Islamist extremists. Jordan's King Abdullah II has called for the "quiet majority of Muslims" to "take back our religion from the vocal, violent, and ignorant extremists...."40 The Grand Sheik of the al-Azhar Mosque in Cairo, Sheik Muhammad Sayyed Tantawi, has consistently spoken out against acts of terrorism. Representing the highest spiritual authority for Sunni Muslims, he has condemned suicide bombings against Israelis and characterized "extremism" as "the enemy of Islam." "41 Public opinion data from polls conducted by the Pew Research Center indicate substantial declines in the percentages of Muslims supporting suicide bombing and other forms of violence, with the percentage change in Jordan particularly significant in the aftermath of the terrorist attack in Amman in $2005 .{ }^{42}$ The fact is that the militant radical message is largely rejected within the Muslim world as being inconsistent with the most fundamental teachings and values of Islam and as lacking relevance to the realities of modern life.

38 Sayyid Abul Ala Mawdudi, “Jihad in Islam,” lecture delivered in Lahore on Iqbal Day (13 April 1939), reprinted in Voices of Terror, ed. Laqueur, 398.

39

Osama Bin Laden was reported to have obtained approval from a Saudi cleric for the use of a nuclear weapon against the United States. Mark A. Gabriel has observed that Al-Zawahiri offers the rationale for killing innocent bystanders in his book entitled Healing the Breast of the Believers, referencing the following Quranic verse: "Fight against them so that Allah will punish them by your hands and disgrace them and give you victory over them and heal the breasts of the believing people, and remove the anger of their believers' hearts..." Surah 9: 13-15; translated by Mark A. Gabriel, Journey Into the Mind, 56-57; also see Osama Bin Laden, "Jihad Against Jews and Crusaders," World Islamic Front Statement (23 February 1998).

40 “Jordan's King Abdullah Pushes for Moderation,” Washington Post (14 September 2005).

41 See "Grand Sheikh Condemns Suicide Bombings," BBC News (4 December 2001); and “Cleric Condemns Suicide Attacks,” BBC News (11 July 2003).

42

Prior to the terrorist attack in Amman in 2005, 57 percent of Jordanians viewed suicide attacks as "often" or "sometimes" justified, with the figure declining to 27 percent in the aftermath of the attack. See Europe's Muslims More Moderate: The Great Divide: How Westerners and Muslims View Each Other (Washington D.C.: The Pew Global Attitudes Project, 22 June 2006); available at http://pewglobal.org/reports/pdf/253.pdf. 
Islamist extremists constitute only a small portion of the some 1.4 billion Muslims worldwide. A strategy to counter ideological support for terrorism should entertain no illusions of seeking to influence the hard-core, radically inspired terrorist, but rather should identify and then discredit and isolate Islamist extremists. Partnering with the Muslim world in a joint struggle against an ideology that has and will continue to bring harm to open societies and ensuring that the Islamists are thwarted in their attempts to attract additional recruits holds the most promise for long-term success. Osama bin Laden attempts to characterize this conflict as a religious war, referring to "a new crusade led by America against Islamic nations," and calling for the umma to "unite to defend Islam." 43 The enemy should be clearly defined; the threat comes from the small extremist core, not from Islam or most of the Muslim world. Failure to precisely distinguish the source of the threat will make it easier for extremists to manipulate greater numbers within the Muslim world to advance their political aspirations by depicting the nature of this conflict as a war against Islam.

The importance of appropriate terminology cannot be underestimated. Language or terminology must be carefully calibrated, with the intention of advancing cooperation and consensus in executing policy. References to the "war on terror" or "Islamofascists" may have a certain resonance or political utility on the domestic front, but such references have surely been misunderstood by our traditional allies and potential partners, and will not help to win "hearts and minds" in the Muslim world. Even in instances in which the U.S. shares a high degree of substantive compatibility with respect to efforts to address the ideological agenda of terrorists, the use of such references can be polarizing and hinder cooperation.

In 2006, both the NATO-Russia Council and the U.S.-Russia Working Group on Counterterrorism (CTWG) introduced the issue of ideological support for terrorism as a priority for advancing collaboration in countering terrorism. ${ }^{44}$ In conjunction with the anniversary celebration of the establishment of the NRC, a major international conference will be held in Ankara, Turkey, in May 2007 to explore options for developing cooperation in combating religious extremism that fuels terrorist activity.

There are several specific areas where the United States, NATO, and Russiaworking with Muslim nations - might begin to build a comprehensive approach for combating militant religious extremism. While certainly not an exhaustive list of options, several factors for consideration and recommendations have emerged from re-

43 “Correspondent Meets with Opposition Leader Bin Laden,” Channel 4 (London) (20 February 1997); and "Pakistan Interviews Usama Bin Ladin," Islamabad, Pakistan (18 March 1997), cited in Christopher M. Blanchard, “Al Qaeda: Statements and Evolving Ideology,” CRS Report for Congress (26 January 2006; updated 24 January 2007), available at http://fpc.state.gov/documents/organization/80743.pdf.

Author's interviews with Igor A. Neverov, Director, North America Department, Ministry of Foreign Affairs, Russian Federation, October 2006; Nerissa J. Cook, Director, Office of Policy and Global Issues, Bureau of European and Eurasian Affairs, U.S. State Department, November 2006; and periodic discussions with Kerem Alp, NATO-Russia Council, NATO, November-December 2006. 
cent discussions (enlisting wide international participation) devoted to this topic at the Marshall Center. These suggestions define practical areas for cooperation, and might provide some of the essential elements of a long-term, comprehensive strategy to combat ideological support for terrorism.

\section{Dialogue and Domestic and International Institutional Coordination}

No nation has the resources to support "talk shops" for endless discussion that fail to yield measurable outcomes. However, developing an effective strategy for countering ideological support for terrorism will not be achieved without a commitment to ongoing international discussion and consultation. The progress made by the international community in moving toward a common definition of terrorism has resulted from honest and open discussion of assumptions and perspectives in the United Nations and other international forums. Russia’s Foreign Minister, Sergei Lavrov, recently reinforced the need to "fight terrorism with a single standard...." 45 Arriving at a "single standard," or a well coordinated strategy, can only be achieved through encouraging routine and sustained dialogue.

For the United States, devoting time and resources to promoting such discussions demonstrates a respect for the potential contributions of partner nations and helps to facilitate the development of a shared understanding of perspectives and professional associations that will be so valuable in dealing with this challenge in the years to come. Such exchanges can contribute to overcoming the lack of trust and suspicion of U.S. intentions that is so prevalent today, especially in the Muslim world.

U.S. government efforts in Public Diplomacy/Public Affairs (State Department) and Strategic Communication/PSYOP (Department of Defense) must be coordinated and directed toward developing a common and coherent information strategy. Mechanisms have been established for the periodic discussion of approaches, themes, and messages between various agencies sharing responsibility for countering ideological support for terrorism (State, Defense, Intelligence, etc.). Joint seminars and routine consultations between the Pentagon, State Department, and other U.S. government agencies have and will continue to facilitate better coordination and understanding of issues. Implementing an effective strategy for countering ideological support for terrorism will require not only optimal domestic agency coordination, but also should lead to the next step: inviting greater international involvement in U.S. government intra-agency forums. The NRC, CTWG, and other groups that are working to unite nations to counter terrorism provide promising mechanisms for directing resources toward developing common approaches to deal with this challenge.

45 “States Harboring Terrorists Should Comply with UN Acts," Novosti (10 December 2005). For an excellent discussion concerning the need for an internationally accepted definition of terrorism, see Boaz Ganor, The Counter-Terrorism Puzzle: A Guide for Decision Makers (London: Transaction Publishers, 2005), 1-24. 


\section{Discrediting the Islamist Extremist Agenda}

A global "hearts and minds" strategy must offer acceptable alternatives to the totalitarian vision and jihad-driven violence promoted by Islamist extremists. Democracy, justice, rule of law, and economic opportunity may have wide appeal, even in the cases of societies that are divided by ethno-religious loyalties and suffer from relative economic disadvantage. The channels for participating in the political process or resolving grievances available in established democratic systems can provide appropriate and effective alternatives to violence and terrorism for those seeking to achieve political objectives. Nevertheless, building democratic nations in cultural contexts that lack such traditions will involve a long-term, patient commitment, and requires much more than simply holding elections. The primary impetus for democratic transition must come from within the society; the creation of democratic institutions and a civic society will mature over a period of decades, not a few months or even years.

One of the major challenges is that, in many respects, secular societies are fundamentally inconsistent with Islam. As Professor Seeyed Hossein Nasr of Tehran University observes,

If Muslims were to accept in principle the separation of religion from the domain of public life (which would then become secularized, as it has in the West to an ever greater degree since the Renaissance), they would have to abandon the doctrine of Unity that lies at the heart of the Islamic message. They would have to act against the Sunnah of the Prophet and fourteen centuries of the unfolding of the Islamic tradition. ${ }^{46}$

Secularist and modernist forces within the Muslim world face the challenge of balancing adherence to Islamic values, traditions, and institutions with introducing concepts of democratic governance.

Rather than adopting a rigid checklist to measure progress in democratic development based on the Western experience, it seems more realistic and potentially productive to recognize that democratization must advance in a manner that will be consistent with the unique circumstances of any society. Attempting to impose democratic practices or standards on reluctant societies is likely to only engender greater resistance. Specialists from Muslim societies often refer to the overwhelming sense of "humiliation" or "resentment" that exists in these societies' "encounter with the West." ${ }^{, 47}$ Democracy should be encouraged, but it is critical not to further aggravate these sentiments by attempting to impose a system of governance before the society is prepared to accept change.

The United States and other democratic societies will also encounter difficulties in enlisting the support of semi-authoritarian nations that would have a great deal to contribute to the combating terrorist groups and methods, but may not be willing to lend

46 Seyyed Hossein Nasr, Islam, Religion, History and Civilization (San Francisco: Harper Collins, 2003), 113.

47 Ladan Boroumand and Roya Boroumand, “Terror, Islam, and Democracy," Journal of Democracy 13:2 (April 2002): 16. 
legitimacy to promoting ideas and values to counter the ideological message of terrorists. We will have to work together with partners throughout the world in finding the proper balance between protecting civil liberties and securing free and open nations against the terrorist threat. At what point do nations undermine the basis for a democratic society in attempting to manage religious extremism? ${ }^{48}$ How far can nations go in regulating Web sites, for example, when those sites are used to recruit terrorists and organize violent attacks? The cyber sphere will continue to present new challenges for democratic societies in weighing the appropriate levels of control when the technology is manipulated for purposes of fostering destruction and violence.

In an effort to de-legitimize the ideological underpinnings of radical Islamism, it is critical to expose the vision offered by Al Qaeda and other Islamist militants for the future of the international order. The ideological mind-set for Islamist extremism includes a worldview characterized by a sense of crisis seeking redemption by violence. The imposition of a fanatic totalitarian theocratic order hardly seems like a realistic or appealing prospect for today's international community, or for most of the world's Muslim population.

Women in Muslim communities offer a great potential contribution to democratization and countering support for terrorism. Muslim women are increasingly represented in the professions, and are critical in fostering the values of society through their influence in the family. Bin Laden repeatedly argued that Afghanistan had become a model Islamic state under the Taliban. ${ }^{49}$ Despite differing Western and Muslim mutual perceptions regarding the issue of "respect for women," there is no debating the fact that women suffered tremendous injustice, deprivation, and humiliation under the Taliban order. ${ }^{50}$ The experience of women under the Taliban is fortunately not illustrative of the conditions under which women live throughout the entire Muslim world, and it is important to appreciate that realization of the core aspirations and objectives of the Islamist jihadist would be unacceptable to most women of the international community of the twenty-first century. Muslim women should be encouraged to become involved in discrediting the oppressive Islamist agenda and the tactics of violence and suicidal destruction.

48 A French political scientist, Dr. Sebastien Peyrouse, argues that vestiges of authoritarianism remain in certain Central Asian nations with respect to religious freedom and tolerance of extremist tendencies in Islam. Sebastian Peyrouse, lecture delivered on "Islam and Politics in Central Asia: A Response to Globalization," Woodrow Wilson International Center for Scholars, Washington D.C., 21 November 2006.

“Al Jazeera Program on Bin Laden,” Al Jazeera Television (Doha, Qatar) (10 June 1999); cited in Blanchard, “Al Qaeda: Statements and Evolving Ideology,” 3.

50 In response to the question “Are Muslims Respectful of Women?” non-Muslims in Great Britain replied 26 percent Yes and 59 percent No; United States, 19 percent Yes and 69 percent No; France, 23 percent Yes and 77 percent No; Germany, 17 percent Yes and 80 percent No. In response to the question “Are Westerners Respectful of Women?” Muslims in Jordan replied 38 percent Yes and 53 percent No; Pakistan, 22 percent Yes and 52 percent No; Indonesia, 38 percent Yes and 50 percent No; and Turkey, 42 percent Yes and 39 percent No. "Europe’s Muslims More Moderate/The Great Divide.” 
Nations committed to combating terrorism must continue to devote attention and resources to addressing the underlying societal forces that create the environments that fuel terrorism. Much of the appeal of Hamas in Palestine and Hezbollah in Lebanon results from their ability to meet the desperate social service needs in war-ravaged societies. The United States, Russia, and other nations are tapping the support of their private sectors to contribute to the counterterrorism effort. Socially responsible private industry can create the economic opportunities, training programs, and career alternatives for those in despair. We must provide potential recruits with an alternative to membership in terrorist movements.

Disseminating messages emphasizing the common positive values (family, dignity, justice) shared by both Western or non-Muslim and Muslim societies can contribute to building common ground and improving impressions. Messages should also promote an appreciation of shared respect for the accomplishments and contributions of diverse societies and practices. Television, media, and information technologies should be fully utilized to focus public attention on the atrocities suffered by the victims of terrorism. Revealing the plight of the victims can help to develop global norms that stigmatize terrorist acts. The efforts of international diplomatic and security organizations toward publicly exposing the vision and behavior of Islamists should gradually contribute to unifying world opinion, thus eroding the potential of extremists for gaining greater influence.

\section{Engaging Muslim Communities: Limitations and Responsibilities}

It seems obvious that leaders within Muslim societies have a critical contribution to make in discrediting the ideology of terrorists. The responsibility for scriptural interpretation and managing teaching in educational and religious institutions must rest with the designated leadership and religious authorities in Muslim communities. Success in the competition of ideas will depend on the discernment, guidance, and response of current and future generations of Muslim communities.

Leading specialists on politics and Islam share the assessment that the spiritual foundations and traditions of Islam provide the best solution to counter the ideology of Islamist terrorism. Dr. Mustapha Benchenane, Professor of Political Science at Université Rene Descartes in Paris, contends that Islam should be used to discredit Islamism. He argues that the scriptural teachings of Islam are inconsistent with the violence and hate that characterize the message and behavior of the Islamists. ${ }^{51}$ Similarly, Dr. Abdeslam Maghraoui, Director of the Muslim World Initiative at the United States Institute of Peace, argues that "the problem of 'religious extremism' in the Muslim world is an ideological challenge best confronted by drawing on Islam's humanist and progressive

51 Presentation by Professor Mustapha Benchenane (and discussion with author) delivered at the conference entitled "Countering Ideological Support for Terrorism/Lessons Learned and Future Policy: Interdisciplinary, Theological, and International/Regional Perspectives, Marshall Center, Garmisch-Partenkirchen, Germany, 15 September 2006. 
traditions." 52 Iranian scholars Ladan Boroumand and Roya Boroumand, writing in the Journal of Democracy, argue that there is "in the history of Islam no precedent for the utterly unrestrained violence of Al Qaeda or the Hezbollah.” They assert: “To kill oneself while wantonly murdering women, children, and people of all religions and descriptions-let us not forget that Muslims too worked at the Trade Center-has nothing to do with Islam..." 53 Recent public discussions held in London and other cities between Muslim clerics and leading figures among the Islamist extremists expose the sharp divide within Islam regarding the interpretation and teachings of the Koran.

Again, in order to avoid creating further divisions or misunderstandings, any counterterrorism initiatives on the part of the transatlantic community (NRC, CTWG, and others) designed to address ideological support for terrorism must include collaboration with the Muslim world. Secular nations with large Muslim populations may have a particularly important contribution to make in bridging ties with Muslim nations. There are certainly limitations in engaging Muslim communities. It is often difficult to discern the legitimate source of authority in Islam. Islam has no equivalent to a single religious authority, such as the Pope of the Roman Catholic Church. The diffuse nature of authority in Islam leaves the faith vulnerable to exploitation by self-appointed extremist clerics and complicates the work for legitimate and responsible religious authorities in discounting distortions or misinterpretations of sacred teachings. In addition, many Muslim religious leaders have an understandable reluctance to cooperate with Western or secular nations, because such an association can compromise their credibility or even security. A highly visible U.S./transatlantic campaign promoting moderation over extremism in the Muslim world is likely to be counterproductive. The challenge is to strike the appropriate balance in supporting Muslim communities committed to countering extremism without in any way assuming an excessively intrusive role.

\section{Lessons Learned and Best Practices}

Convening gatherings of counterterrorism professionals drawn from military and security communities around the world to exchange experiences in countering ideological support for terrorism promises to be among the most effective methods in preparing a coherent effort to combat the ideological underpinnings of Islamist extremism. These discussions tend to be quite concrete, offering specific recommendations based on actual experience in dealing with terrorists motivated by religious extremism in different nations. Discussions cover a wide spectrum of issues, including monitoring the activities of radical terrorists, distribution of literature, techniques for thwarting recruitment

52 Presentation by Dr. Abdeslam Maghraoui delivered at the conference entitled "Countering Ideological Support for Terrorism/Lessons Learned and Future Policy: Interdisciplinary, Theological, and International/Regional Perspectives,” Marshall Center, Garmisch-Partenkirchen, Germany, 15 September 2006; and Abdeslam M. Maghraoui, "American Foreign Policy and Islamic Renewal,” United States Institute of Peace, Special Report No. 164 (July 2006) (reprinted from the original in this volume, pp. 26-40).

Boroumand and Boroumand, "Terror, Islam, and Democracy," 6. 
efforts, working with imams to intervene by counseling young recruits, and attempting to address underlying causes, such as implementing efforts to combat poverty.

Such collaborative exchange can contribute to building "best practices," providing guidance to military/security counterterrorism professionals in techniques for countering ideological support for terrorism. Also, fostering channels of communication among counterterrorism professionals will enhance intelligence sharing, which will in turn bolster efforts to combat radicalism. Again, these military/security counterterrorism networks establish the foundation for managing the day-to-day business of successfully countering terrorism worldwide.

The periodic professional exchanges that occur between nations in promoting the counterterrorism initiatives of the NRC and CTWG also contribute to building best practices. It is important to provide opportunities not only for task oriented collaboration, but also time for reflection and exchange of perspectives on methods and techniques for combating militant radicalism.

\section{Traditional Religions and Interreligious Dialogue}

The potential positive contributions of the world's major religions to resolving conflicts have been underestimated in the state-centric diplomatic community. ${ }^{54}$ The complexity and potential consequences of failing to manage the terrorist threat makes it even more important to enlist the support of clerics and religious authorities, from a wide range of confessional traditions.

Political officials throughout the world are increasingly acknowledging that traditional religions, through interreligious dialogue, could play an important role in addressing the terrorist challenge. In conjunction with the G-8 Summit held in St. Petersburg, Russia in July 2006, Russia's President Vladimir Putin called for "broad dialogue between religions to ward off extremists." 55 Similarly, in January 2006, Philippine President Gloria Macapagal-Arroyo, citing recent progress in reducing the terror-

${ }^{54}$ In a major edited volume entitled Religion, the Missing Dimension of Statecraft, contributors argue that traditional religions have an important contribution to make in resolving the identity-based conflicts of the post-Cold War period. One of the editors, Douglas Johnson, concludes that: "As one looks at the end of the century and beyond, the challenges of preventing or resolving conflict are likely to prove even more formidable than they have in the past. The problems posed by today's ethnic and nationalistic hostilities, whether inter- or intrastate, have shown themselves to be peculiarly resistant to diplomatic compromise. If the goal of achieving peace in meaningful terms is to prove any less elusive, different approaches will be required-approaches that key to deep-rooted human relationships rather than state-centered philosophies. Far greater insight into the human dimension of conflict and its resolution will be required on the part of foreign policy and religious practitioners than has been demonstrated to date." See Douglas Johnston, "Introduction: Beyond Power Politics" in Religion, The Missing Dimension of Statecraft, eds. Douglas Johnston and Cynthia Sampson (Oxford: Oxford University Press, 1994), 7.

55 “Russia’s Putin Calls for Interfaith Dialogue to Oppose Extremism," RIA Novosti (3 July 2006). Putin noted that "ignorance of the fundamentals of religious history makes a man, particularly a young one, vulnerable to dangerous extremist movements.” 
ist threat and negotiating peace in Mindanao, stated that interfaith dialogue was the best "antidote to terrorism." ${ }^{, 56}$ Karen Hughes, the U.S. Undersecretary of State for Public Diplomacy and Public Affairs, emphasized the importance of interfaith dialogue in a recent interview in Prague:

... the world's major faiths have many things in common. The world's major faiths all believe that we should try to live in peace and love for each other, that we should love God and love our neighbor. All believe and teach that life is precious and that the taking of innocent life is wrong. It's important that we talk about these things. Sure, we have differences. We have important theological differences. But we also have much in common. And I think it is very important that we foster that kind of dialogue. ${ }^{57}$

The credibility of terrorists can be undercut by higher authorities challenging the misuse of religion for political purposes. While the recent G-8 meeting was in session, the leaders of the major world religions (Christianity, Islam, Judaism, Buddhism, and others) signed a joint statement that included the following reference to terrorism and extremism:

We condemn terrorism and extremism of any form, as well as attempts to justify them by religion. We consider it our duty to oppose enmity on political, ethnic, or religious grounds. We deplore the activities of pseudo-religious groups and movements destroying freedom and health of people as well as the ethical climate in societies. Using religion as a means for rousing hatred or an excuse for crimes against individuals, morality, and humanity present a major challenge today. This can be addressed only through education and moral foundation. School, mass media, and preaching by religious leaders should return to our contemporaries the full knowledge of their religious tradition which call them to peace and love. ${ }^{58}$

Pope John Paul II also acknowledged the potential contribution of interreligious dialogue in overcoming terrorism: "I am convinced that humanity's great religions should cooperate among themselves to help eliminate the social and cultural causes of terrorism, by teaching the grandeur and dignity of the human being and by favoring an increasing awareness of the unity of the human race."59 His successor Pope Benedict XVI's first visit to Istanbul in November 2006 was an important step toward improving the relationship between the Christian and Muslim communities, and toward creating a basis for cooperation in meeting the most pressing security challenges facing the international community in the twenty-first century.

The ideological foundations of contemporary violent religious extremist groups must be de-legitimized by theological refutation. Interreligious dialogue can focus the

56 “Philippine President Promotes Interfaith Dialogue to Fight Terror,” Manila Times (28 January 2006).

57 “U.S. Undersecretary of State Pushes for More Interfaith Dialogue,” RFE/RL (11 June 2006). 
attention of the communities of the world on the distortions of scriptures relied upon by these groups, and the inconsistencies of their heinous terrorist acts with the shared peaceful teachings of the world's major religions. The responsible leadership of religious authorities working together can help in preventing the escalation of a major twenty-first-century conflict based on religious-ethnic/cultural distinctions.

At the international level, it would be important to include representation from religious communities in forums that are tasked with seeking solutions for how best to counter the "hearts and minds" appeal of terrorism. In local communities, there have been many instances when imams have contributed to efforts to counter radicalism and extremism. Perhaps no single security issue is more suited for government-religious cooperation than countering extremism-motivated terrorism.

\section{Intercultural Research/Educational Cooperation}

Terrorism has not been a major area for focus in academic security studies in the United States. During the years of the U.S.-Soviet confrontation, tremendous resources were invested in cultivating academic centers for studying the Soviet Union. There were a number of leading academic specialists that could be tapped for directing research and offering support in the development of policy and strategy. Terrorism was subsumed within other academic disciplines, and there were few programs or centers in the United States or in other nations devoted to terrorism (the Centre for the Study of Terrorism and Political Violence at the University of St. Andrews in Scotland is among the few). The dedication of limited resources to the study of terrorism has resulted in a scarcity of experts and research in the area.

In formulating an ideological campaign, we need greater clarity on the motives of Islamist terrorists. The current academic and policy literature offers a range of explanations for why people would choose to join a terrorist movement: rational actor; group cohesion; low self-esteem or compensation; religious inspiration; educational background and training. ${ }^{60}$ While there may in fact be multiple profiles for terrorists, it is still necessary to understand what motivates terrorists to act or to voluntarily engage in acts of suicidal martyrdom when we attempt to formulate responses to counter terrorist ideology.

Additional objective and rigorous case study research across different national and cultural contexts will provide a basis for assessing the success of various measures implemented to counter extremism. For example, investigations on the impact of govern-

60 Jerrold M. Post, "Psychological Operations and Counterterrorism,” Joint Force Quarterly 37 (2005): 105-10; Marc Sageman, Understanding Terror Networks (Philadelphia: University of Pennsylvania Press, 2004); Martha Crenshaw, “The Logic of Terrorism: Terrorist Behavior as a Product of Strategic Choice,” in Origins of Terrorism: Psychologies, Ideologies, Theologies, States of Mind, ed. Walter Reich (Washington D.C.: Woodrow Wilson Center Press and Johns Hopkins University Press, 1998); Robert A. Pape, Dying to Win: The Strategic Logic of Suicide Terrorism (New York: Random House, 2005); and Mia Bloom, Dying to Kill: The Allure of Suicide of Terrorism (New York: Columbia University Press, 2005). 
ment-initiated multicultural campaigns in the U.K. and Singapore contained in this volume illustrate the type of case study research that can over time provide a basis for evaluating effectiveness in implementing strategies to counter extremism. New institutes, such as the Combating Terrorism Center, established in 2003 at the United States Military Academy at West Point, will improve our understanding of the sources of terrorist motivation and can help support policy formulation. ${ }^{61}$ The U.S. military community has acknowledged the importance of enhancing educational efforts to strengthen its understanding of differing cultures and traditions and to better prepare the military leadership for working constructively in diverse societies. ${ }^{62}$ Lt. Col. Fred T. Krawchuk, Director of Strategic Communication for U.S. Pacific Command, emphasizes the importance of enhancing cultural adeptness in forming an effective strategic information campaign. ${ }^{63}$ In the aftermath of September 11, the Fulbright Council for the International Exchange of Scholars established the Visiting Specialist Program and the Understanding Contemporary Islam Program to facilitate the hosting of scholars from nations with significant Muslim populations in U.S.-based universities. These programs seek to improve the understanding of Islam in American educational institutions and communities and promote ongoing collaborative research with Muslim scholars.

NATO's Science for Peace and Security Program provides an excellent model for facilitating international collaborative research. The NRC might consider sponsoring joint collaborative research projects involving both academic and security/policy analysts from both NRC and Muslim nations engaged in work on terrorism and countering ideological support for terrorism. Investments in strengthening such academic collaboration will improve knowledge and intercultural understanding on the sources of violent extremism, and may perhaps yield significant policy contributions.

\section{Importance of Consistency of Intentions in Messages and Policy}

It is critical that the effort to win the hearts and minds of the potential audience for Islamist extremist movements not be perceived as an attempt to manipulate societies or practice ideological "spin." The importance of trusting the messenger cannot be overestimated for any successful strategic communication effort. To be effective, public diplomacy efforts and the messages delivered must be consistent with substantive policy and behavior. Otherwise, any public diplomacy or communication effort is likely to be

61 The Center recently released a major study, for example, which "identifies who the most influential people are among the Jihadi thinking class, what they are thinking, and where the movement is most vulnerable ideologically.” See Jarret Brachman, ed., Militant Ideology Atlas (West Point: Combating Terrorism Center, November 2006).

Lt.Col. Andrew W. Stewart of the U.S. Army War College argued in a recent article that, "Success in promoting the U.S. worldview, and winning the Global War on Terrorism (GWOT) specifically, rests in Americans recognizing their own cultural uniqueness and developing a high level of cultural savvy in dealing with more traditional cultures.” See Lt. Col. Andrew W. Stewart, "Friction in U.S. Foreign Policy: Cultural Difficulties in the World," Carlisle Papers in Security Studies (Carlisle, PA: Strategic Studies Institute, U.S. Army War College, June 2006).

63 Krawchuk, "Strategic Communication." 
dismissed as simply propaganda or attempts to manipulate perceptions. Implementing a comprehensive strategy for countering ideological support for terrorism must include constant assessment of the impact of policy priorities and choices. The legacy of U.S. policy that assigned greater priority to regional stability over democracy in the Middle East during the years of the Cold War and beyond has left many in the region skeptical regarding U.S. intentions. ${ }^{64}$ Striving for consistency between our stated intentions and our actions will weaken charges that the U.S. is hypocritical or pursuing double standards, and may contribute to favorably influencing the hearts and minds of the next generation in the Muslim world.

Discussions devoted to countering ideological support for terrorism with colleagues from the Middle East will invariably turn to seeking a sustainable resolution of the Israeli-Palestinian conflict. There may be some truth to the claim that reaching a settlement for this issue would not bring an end to terrorism, but it is also true that progress on the Israeli-Palestinian problem could help to improve the psychological climate in the region and eliminate a major source of the outrage that supports terrorist recruitment. Renewed international attention to addressing some of the relevant critical policy issues - such as the Israeli-Palestinian settlement and the integration of Muslims in European and other communities-will demonstrate the sincerity of intention that exists behind efforts to counter the sources of militant religious extremism that threaten the security of free societies throughout the world community.

64 Stephen A. Cook, writing recently in Foreign Affairs, observes that ranking democratization beneath the interests of preserving security and stability has led to pervasive skepticism throughout the Arab world. See Stephen A. Cook, "The Right Way to Promote Arab Reform,” Foreign Affairs 84:2 (March-April 2005): 91-102. 


\section{THE QUARTERLY JOURNAL}

\section{Bibliography}

Bloom, Mia. Dying to Kill: The Allure of Suicide of Terrorism. New York: Columbia University Press, 2005.

Boroumand, Ladan, and Roya Boroumand. "Terror, Islam, and Democracy." Journal of Democracy 13, no. 2 (2002).

Cook, Stephen A. "The Right Way to Promote Arab Reform." Foreign Affairs 84, no. 2 (2005).

Cook, Stephen A. "The Right Way to Promote Arab Reform." Foreign Affairs 84, no. 2 (2005).

Crenshaw, Martha. "The Logic of Terrorism: Terrorist Behavior as a Product of Strategic Choice." In Origins of Terrorism: Psychologies, Ideologies, Theologies, States of Mind. Washington D.C.: Woodrow Wilson Center Press and Johns Hopkins, 1998.

Gabriel, Mark A. Journey Into the Mind of an Islamic Terrorist . Lake Mary, FL: Front Line, 2006.

Gaddis, John Lewis. Strategies of Containment: A Critical Appraisal of Postwar American National Security Policy . New York: Oxford University Press, 1982.

Hunter, Shireen T.. Islam in Russia: The Politics of Identity and Security. New York: M. E. Sharpe, 2004.

Lavrov, Sergei. "Statement at the 59th Session of the UN General Assembly." International Affairs (2004).

Pape, Robert A.. Dying to Win: The Strategic Logic of Suicide Terrorism . New York: Random House, 2005.

Plugatarev, Igor. "Local Conflicts 2005/A Sluggish War on the Caliphate." Nezavisimoye Voyennoye Obozreniye 49 (2005).

Post, Jerrold M. "Psychological Operations and Counterterrorism." Joint Force Quarterly37 (2005).

Qutb, Sayyid. "Jihad in the Cause of God." In Voices of Terror: Manifestos, Writings and Manuals of Al Qaeda, Hamas, and other Terrorists From Around the World and Throughout the Ages. New York: Reed Press, 2004.

Titarenko, Mikhail. "The Islamic World and Russian Foreign Policy." International Affairs 4 (2005). 